\title{
HEPATIC TUMOURS IN CHILDHOOD AND THEIR TREATMENT BY MAJOR HEPATIC RESECTION*
}

BY

\author{
H. H. NIXON \\ From The Hospital for Sick Children, Great Ormond Street, London
}

Hepatic tumours in childhood are not common, and when seven cases were seen within a short time it seemed worth while to report them (see Table overleaf).

\section{Pathology}

Five were described as hepatoblastomas. These are usually considered as embryomas analogous to the nephroblastoma. Though only the epithelial elements of the liver arise from the hepatic diverticulum of the primitive gut, the derivatives

\footnotetext{
* A paper read at a meeting of the British Association of Paediatric Surgeons in Rotterdam, September 1964
}

of the mass of mesenchyme into which it grows may take part in the neoplasia. Case 3 had an appearance suggestive of gargoylism, and punch biopsies were suggestive of storage disease as were some bone changes. Open biopsy and later examination of the operative specimen did not confirm this, the liver cells showing abundant fatty degeneration but no evidence of storage disease.

Case 6 was described as a hepatic carcinoma arising in an otherwise normal liver (Fig. 1). The tumour consisted of pleomorphic cells having some of the characteristics and arrangement of liver parenchyma. No embryonic mesenchyme was seen.

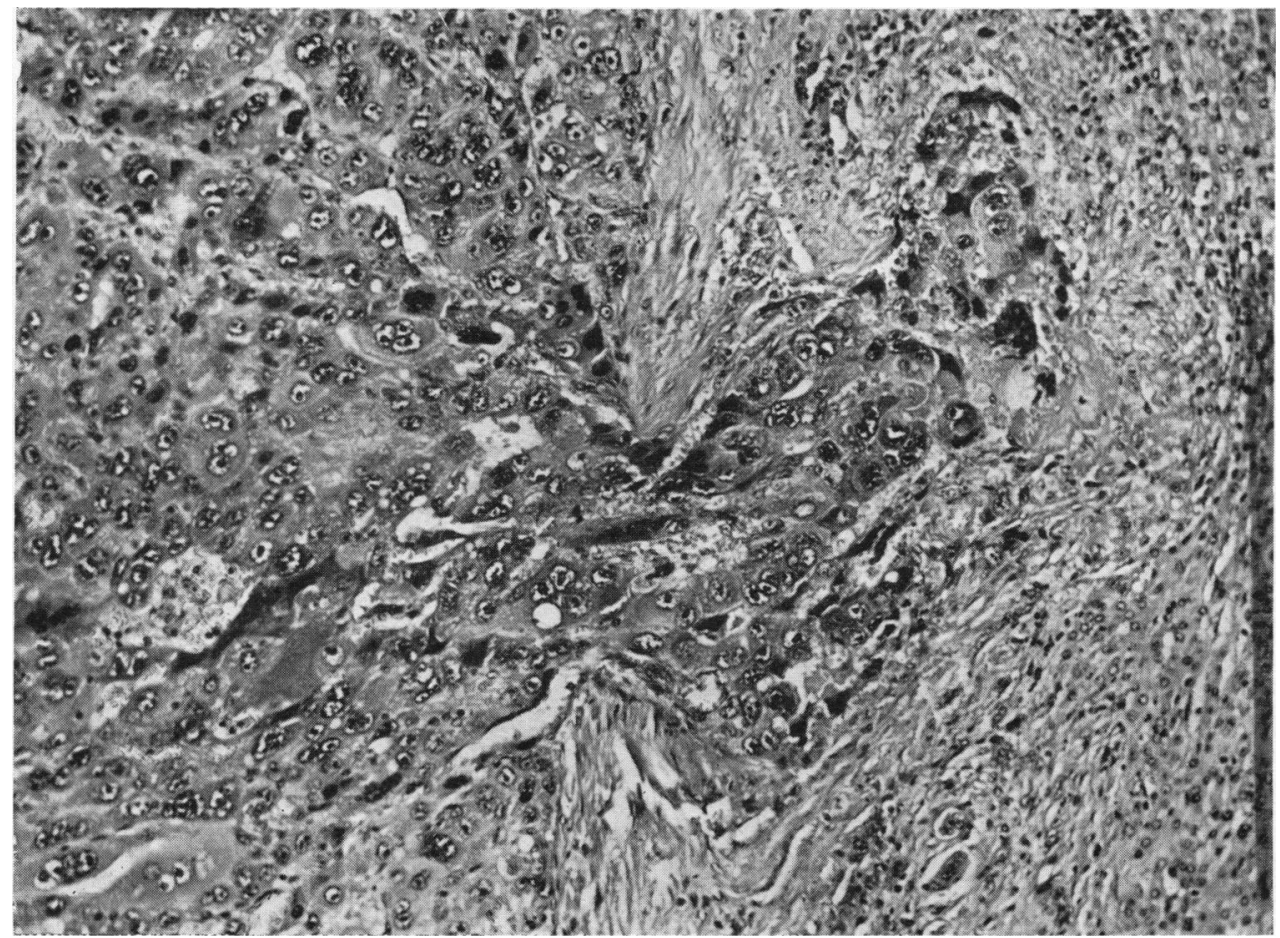

FIG. 1.-Case 1 : carcinoma arising in normal liver. $(\times 130$. 
AGE, PRESENTING SYMPTOMS, RESULTS馬F

\begin{tabular}{|c|c|c|c|c|c|}
\hline \multicolumn{3}{|c|}{ Case No., Age, and Sex } & \multirow{3}{*}{$\begin{array}{c}\text { Tumour } \\
\text { Hepatoblastoma } \\
\text { Hepatoblastoma } \\
\text { Hepatoblastoma }\end{array}$} & \multirow{3}{*}{$\begin{array}{l}\text { Presenting Symptoms } \\
\text { Malaise; palpable } \\
\text { tumour } \\
\text { Palpable tumour } \\
\text { Hepatosplenomegaly } \\
\text { (appearance like } \\
\text { gargoylism) }\end{array}$} & \multirow{2}{*}{$\frac{\text { Duration }}{1 \mathrm{mth}}$} \\
\hline 1 & 9 yr. & $\mathbf{M}$ & & & \\
\hline $\begin{array}{l}2 \\
3\end{array}$ & $\begin{array}{l}7 \text { mth. } \\
2 \text { yr. }\end{array}$ & $\begin{array}{l}\mathbf{F} \\
\mathbf{M}\end{array}$ & & & $18 \stackrel{?}{\text { mth. }}$ \\
\hline $\begin{array}{l}4 \\
5\end{array}$ & $\begin{array}{l}5 \mathrm{mth} . \\
1 \frac{1}{2} \mathrm{yr} .\end{array}$ & $\begin{array}{l}\mathbf{M} \\
\mathbf{M}\end{array}$ & $\begin{array}{l}\text { Hepatoblastoma } \\
\text { Hepatoblastoma }\end{array}$ & $\begin{array}{l}\text { Palpable tumour } \\
\text { Irritable; } \\
\text { pale; }\end{array}$ & $\begin{array}{l}10 \mathrm{dy} . \\
10 \mathrm{wk} . \\
6 \mathrm{wk} .\end{array}$ \\
\hline 6 & $7 \mathrm{yr}$. & $\mathbf{M}$ & $\begin{array}{l}\text { Carcinoma in } \\
\text { normal liver }\end{array}$ & Loss of weight; & $2 \mathrm{mth}$. \\
\hline 7 & 1 wk. & $\mathbf{M}$ & Hamartoma & $\begin{array}{l}\text { Palpable mass } \\
\text { at birth }\end{array}$ & 1 wk. \\
\hline
\end{tabular}

This must be very unusual, for the commonest age of appearance of carcinoma of the liver is in the sixth decade and it is usually associated with cirrhosis.

However, the difference in histological pattern may be one of degree, and Willis (1948) points out 'that the distinction between truly embryonic liver cell tumours and ordinary hepatomas arising in childhood may be neither histologically possible nor theoretically valid', and goes on to say 'suffice it to recognize that there are tumours of liver tissue of unquestionable embryonic qualities'.

The remaining case was a hamartoma, containing much vascular tissue.

\section{Presentation}

In two cases vague malaise and in one weight loss had led to examination revealing the palpable tumour. In the others the palpation of the mass was the first sign of trouble. Six of the seven were boys.

\section{Treatment}

Operation. The first boy presented with a large abdominal swelling. Laparotomy and frozen section biopsy confirmed this to be a hepatoblastoma filling the right lobe of the liver. 1,666 g. of soft tumour were scooped out of the cavity to relieve abdominal distension and the child returned home. He died four months later.

Reconsidering this case, it was felt that the mere size of the tumour should have been no justification for such a palliative approach, for hepatoblastomas grow locally but metastasize late (Steiner, 1938). The next six liver tumours were therefore treated by the following major resections: 2 right hemihepatectomies, 2 right hepatic lobectomies, 1 left hepatic lobectomy, and 1 left hemihepatectomy with partial right lobectomy.

The liver has joined those organs whose vascular hila have been charted so that major resections can be performed in a planned manner. I have found Hobsley's re-evaluation of the anatomy invaluable (Hobsley, 1958; Hobsley and Lloyd-Davies, 1959). The main divisions are into right and left halves along the principal plane from gall-bladder fossa to the right side of the inferior vena cava, or into right and left lobes along the falciform ligament (Fig. 2). The liver is unusual in having two hila, the bile-ducts, hepatic arteries, and portal veins all in the porta hepatis, and the hepatic veins separately leaving the liver near the upper border posteriorly. Unfortunately their drainage areas do not correspond. The Glissonian system fundamentally forms right and left halves, whereas the hepatic veins divide the liver into three areas with the central vein territory draining part of the right and left halves (Fig. 3). In this overlap and in the inaccessibility of the hepatic veins to demonstration by dissection lie the main technical problems of hepatic resection.

For right-sided resections the preferred incision is an oblique thoraco-abdominal one. The abdominal part is made first. Exploration of the abdomen and dissection of the porta hepatis to confirm operability precede opening of the chest and division of the diaphragm right into the opening for the inferior vena cava. Slings to control the cava should then be placed above the diaphragm and below the liver. It is usual to rotate the liver to the left to expose the right hepatic vein, and if necessary the central vein. Mercadier approaches the veins from the front, retracting the liver downwards and dissecting into the liver tissue. The latter may be easier depending on the distortion produced by the particular tumour, but the stout fascial investment of the vena cava in this region may be troublesome. I found the correct perivascular plane more easily by starting the dissection above the diaphragm and working down.

The left lobectomy (in a 1-week-old baby) proved a simple procedure and was completed from the abdomen and without control of the vena cava. 
OPERATION, AND PROGRESS IN 7 CASES

\begin{tabular}{|c|c|c|}
\hline Operation* & Result & Progress \\
\hline $\begin{array}{l}\text { Piecemeal evacuation of } \\
\text { tumour } \\
\text { Right hepatic lobectomy } \\
\text { Right hemihepatectomy }\end{array}$ & $\begin{array}{l}\text { Survival } \\
\text { Died (thrombosis IVC) } \\
\text { Survival }\end{array}$ & $\begin{array}{l}\text { Tumour discharge from wound; } \\
\text { died } 4 \mathrm{mth} \text {. later } \\
\text { Well } 1 \mathrm{yr} \text {. later }\end{array}$ \\
\hline $\begin{array}{l}\text { Right hemihepatectomy } \\
\text { (1) Right hemihepatectomy } \\
\text { (2) Relief of adhesion } \\
\text { obstruction } \\
\text { Left hemihepatectomy with } \\
\text { partial right lobectomy } \\
\text { Left lobectomy }\end{array}$ & $\begin{array}{l}\text { Died (pulmonary infarcts) } \\
\text { Survival } \\
\text { Survival } \\
\text { Survival }\end{array}$ & $\begin{array}{l}\text { Methotrexate; died } 3 \mathrm{mth} \text {. later } \\
\text { (pulmonary metastases and } \\
\text { local recurrence) } \\
\text { Methotrexate; well } 6 \mathrm{mth} \text {. later } \\
\text { Well } 6 \mathrm{mth} \text {. later }\end{array}$ \\
\hline
\end{tabular}

* See Fig. 4.

The 'extended left hemihepatectomy' removed all but half of the right lobe with the gall-bladder attached. It was possible to divide the right lobe in a curved line so as to preserve the divisions of the right hepatic vein, which drained the remaining part of the lobe, and yet keep clear of the tumour. The right thoraco-abdominal approach was used, with control of the inferior vena cava.

In each of the resections the liver substance was divided with the diathermy, a few individual vessels being caught and undersewn as necessary. The biliary duct system was not drained. A tube drain into Morison's pouch only drained a little blood. Biliary leakage has not been noticeable.

Complications. The first post-operative death was due to thrombosis of the inferior vena cava following trauma in attempting to control bleeding from the hepatic veins. Serious bleeding also arose during clearing of the central hepatic vein in the extended left hemihepatectomy, though it was successfully

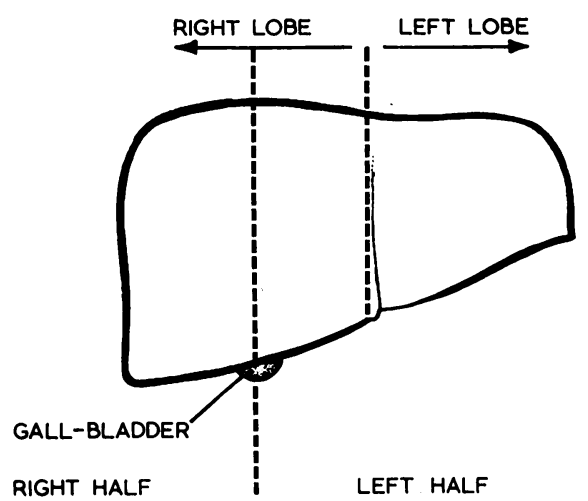

Fig. 2.-Classical division into right and left lobes through plane of falciform ligament and functional division into right and left halves as supplied by right and left branches of Glissonion system (arteries, portal veins, and bile-ducts) through gall-bladder fossa.

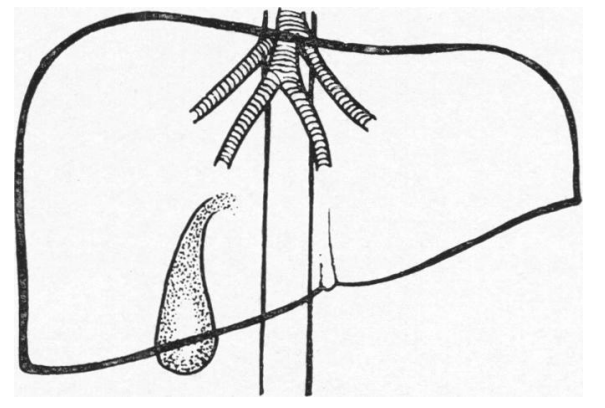

FIG, 3.-Hepatic venous drainage from three sectors-the middle hepatic vein draining an area supplied by right and left branches of the Glissonian system and hence complicating the technique of resection.

controlled. Both these episodes could have been avoided by adequate control of the vena cava by a sling placed above the diaphragm as mentioned above.

The other death occurred 3 days after operation
(A)
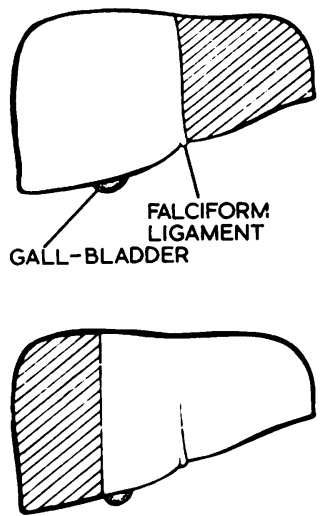

(C)
(B)
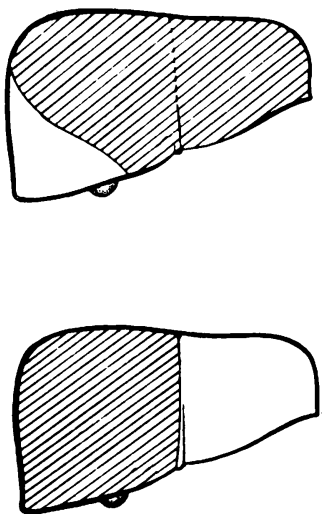

(D)
FIG. 4.-Extent of resections performed (see Table): (A) left lobectomy; (B) left hemihepatectomy; (C) right hemihepatectomy (D) right lobect omy plus partial right hemihepatectomy. 
and was due to infarction of the upper lobes of both lungs. The veins within the abdomen were quite healthy and free of thrombi. It appears that the origin of the pulmonary thrombi was in emboli from the haemorrhagic and necrotic centre of the tumour disturbed during manipulation of the liver.

One right hemihepatectomy developed intestinal obstruction from adherence of a loop of ileum to the raw surface of the liver three weeks after the operation. An attempt had been made to cover the raw area with the mobilized falciform ligament as is usually advised. I have found this somewhat inadequate and have since sutured omentum over the surface instead.

Only one patient in the series (Case 3) showed post-operative signs of liver failure, and in this case the disturbance was temporary.

Two cases have been given methotrexate. Case 5 received $2.5 \mathrm{mg}$. daily for two months after operation; he then developed granulopenia and the drug was discontinued. He died with pulmonary metastases and local recurrence one month later. Case 6 has had the drug for the six months since removal of his hepatic carcinoma and remains well.

\section{Summary}

Four children out of six survived major hepatic resection for tumour. Three remain well for periods of 6 to 12 months after operation. One was an unusual tumour, a hepatic carcinoma in the otherwise normal liver of a child. Comments are made on points of operative technique. Although the bi le-ducts were not drained, significant leakage of bile did not occur, possibly because the liver was divided with diathermy. An aggressive attitude to these tumours seems justified.

My thanks are due to those colleagues who referred the cases to me, and to the late Dr. Martin Bodian and to Drs. Barraclough, Crome, and Ockenden, for the pathological reports. I am indebted to the Department of Medical Illustration at The Hospital for Sick Children, Great Ormond Street, for the photographs and diagrams.

\section{REFERENCES}

Hobsley, M. (1958). Intra-hepatic anatomy: a surgical evaluation. Brit. J. Surg., 45, 635.

- and Lloyd-Davies, O. V. (1959). Survey on partial hepatectomy with especial reference to liver anatomy. In British Surgical Practice, ed. E. R. Carling and J. P. Ross. Surgical Progress, p. 40. Butterworth, London.

Steiner, M. M. (1938). Primary carcinoma of the liver in childhood report of 2 cases with critical review of literature. Amer.J. Dis. Child., 55, 807.

Willis, R. A. (1948). Pathology of Tumours, p. 933. Butterworth, London. 